\title{
ANALISA KEUANGAN TERHADAP HARGA SAHAM BUMN (TELEKOMUIKASI) DIBURSA EFEK INDONESIA
}

\author{
Karnadi \\ Fakultas Ekonomi Universitas Prof.Dr.Hazairin,SH Bengkulu \\ Email : karnadi@unihaz.ac.id \\ Budiman Sakti \\ Fakultas Ekonomi Universitas Prof.Dr.Hazairin,SH Bengkulu \\ Email : budiman@unihaz.ac.id
}

\begin{abstract}
ABSTRAK
Kemajuan teknologi dan komunikasi adalah hal dasar yang menjadikan perusahaan telekomunikasi tempat yang baik untuk berinvestasi. Ketika menilai kinerja perusahaan telekomunikasi, penulis menggunakan ROE, EPS, ROA dan DER sebagai indikator sebagai variabel independen dan harga saham sebagai variabel dependen. Hasilnya, mereka juga berpengaruh signifikan terhadap variabel dependen secara parsial dan simultan. Hasil penelitian menunjukkan bahwa perusahaan telekomunikasi adalah tempat yang baik bagi investor. Karena, perusahaan telah menunjukkan hasil yang baik dari manajemen perusahaan.
\end{abstract}

Kata kunci: roe, eps, roa, der, harga saham

\begin{abstract}
Progress in technology and communication is a basic things that make the telecommunication company a good place to invest. When assessing the performance of telecommunication company, the author use ROE, EPS, ROA and DER as indicators as variable independent and price of shares as dependent variable. The result, they also affect significantly to dependent variable in partial and simultaneous.the result showed that telecommunication companies is a good place for investors. Because, the company has shown good result of management company.
\end{abstract}

Keyword : roe, eps, roa,der, price of share

\section{Pendahuluan}

Indonesia terus melaju kejajaran elite perekonomian dunia. konsumen perusahaan telekomunikasi di Indonesia merupakan salah satu konsumen terbesar di Indonesia, ini disebabkan oleh kemajuan teknologi dan komunikasi yang merupakan suatu kebutuhan utama masyarakat saat ini. Begitu juga dengan perusahaanperusahaan telekomunikasi diindonesia berlomba-lomba menjadi yang terdepan dalam memberikan pelayanan yang terbaik bagi para konsumen . sehingga kebijakan pemerintah Indonesia saat ini dan kedepan akan berfokus untuk menjaga dua motor pertumbuhan, yaitu pasar domestik dan investasi.

Menurut Abdul Halim (dalam Irham 2012:3) investasi pada dasarnya adalah penempatan sejumlah dana pada saat ini dengan harapan untuk mendapatkan keuntungan di masa yang akan datang. Investasi mempunyai peran penting dalam perekonomian suatu negara, pertama investasi mampu menciptakan pendapatan, 
kedua investasi dapat memperluas kapasitas produksi perekonomian dengan cara meningkatkan stock modal. (Todaro dalam Irham,2012:23). Sarana yang paling efektif untu investor dalam melakukan investasi adalah pasar modal. Pasar modal di Indonesia, yaitu bursa efek Indonesia (BEI) menjadi perantara, pertemuan bagi para investor dan industri. Saham adalah salah satu instrumen dalam pasar modal yang paling populer. Pesatnya perkembangan bursa efek Indonesia saat ini tidak dapat dipisahkan dari peran investor yang melakukan transaksi dibursa efek Indonesia. laporan keuangan yaitu media informasi yang digunakan oleh perusahaan yang bersangkutan untuk mengetahui kondisi, prestasi keuangannya kepada pihak-pihak yang berkepentingan, terutama bagi para investor, kreditur, dan pihak manajemen dari perusahaan itu. Dari informasi laporan keuangan tersebut, investor akan memperoleh data ROA (return on asset), ROE (return on equity), EPS (earning per share, dan DER (debt to equity ratio). Penggunaan indikator tersebut akan mempermudah investor dalam menilai kinerja perusahaan untuk menanamkan dananya pada perusahaan tersebut. Dan juga dapat membatu para manajer membuat keputusaan investasi yang lebih baik, mengidentifikasi kesempatan-kesempatan untuk peningkatan kinerja dan mempertimbangkan benefit jangka pendek dan jangka panjang untuk perusahaan.

\section{Metode Penelitian}

Sifat penelitian ini adalah penelitian asosiatif. Menurut Sugiyono (2007:30) penelitian asosiatif adalah penelitian yang tujuannya untuk mengetahui pengaruh variabel independen terhadap variabel dependen. Jenis penelitian ini merupakan jenis penelitian kuantitatif yang dilakukan dengan menguji kebenaran data dalam penentuan dan pemecahan masalah. Menurut Sugiyono (2007:13) penelitian kuantitatif adalah penelitian pada populasi atau sampel tertentu, pengumpulan data menggunakan instrumen penelitian, analisis data bersifat kuantitatif atau statistik yang tujuannya untuk menguji hipotesis yang telah ditetapkan. Sedangkan sumber data dari penelitian ini yaitu sumber data skunder. Data skunder Yaitu data yang diperoleh langsung dari penerbit resminya. Data ini diperoleh dari situs website Bursa Efek Indonesia.

Populasi merupakan keseluruhan objek yang dibatasi oleh kriteria tertentu. yang Dimana objek ini bisa kongkret (misal orang) maupun abstrak (misal sikap). Dengan demikian data populasi yang digunakan dalam penelitian ini yaitu seluruh perusahaan go public yang listing di bursa efek Indonesia. sampel penelitian ini menggunakan metode sampling purposive yaitu sampel dipilih berdasarkan target dan tujuan tertentu atau sampel yang dipilih menggunakan pertimbangan tertentu. Untuk mendapatkan data yang menunjang dalam penelitian ini, penulis melakukan pengumpulan data dengan teknik penelitian kepustakaan yaitu penelitian yang dilakukan dengan cara membaca buku-buku diperpustakaan dan tulisan-tulisan yang berkaitan dengan masalah-masalah yang akan diteliti oleh penulis.

\section{Hasil penelitian dan pembahasan}

PT. Telekomunikasi Indonesia Tbk (persero) biasa disebut Telkom Indonesia atau Telkom saja adalah perusahaan informasi dan komunikasi serta penyedia jasa dan jaringan telekomunikasi secara lengkap di Indonesia. Telkom mengklaim sebagai perusahaan telekomunikasi terbesar di Indonesia, dengan jumlah pelanggan 
telepon tetap sebanyak 15 juta dan pelanggan telepon seluler sebanyak 104 juta. Telkom merupakan salah satu BUMN yang sahamnya saat ini dimiliki oleh pemerintah Indonesia $(52,47 \%)$, dan $47,53 \%$ dimiliki oleh publik, bank of New York, dan investor dalam negeri. Telkom juga menjadi pemegang saham mayoritas di 13 anak perusahaan, termasuk PT telekomunikasi selular (telkomsel). Dari laporan keungan perusahaan telekomunikasi ini, dapat diperoleh data berupa: ROE,EPS,ROA,DER,\& harga saham sebagai berikut:

\section{TABEL I.}

Hasil Olahan Laporan Keuangan

\begin{tabular}{|c|c|c|c|c|c|}
\hline Tahun & ROE & EPS & ROA & DER & $\begin{array}{c}\text { HARGA } \\
\text { SAHAM }\end{array}$ \\
\hline 2004 & 20,9 & 160,3 & 8,25 & 123,6 & 5825 \\
2005 & 22,8 & 158,5 & 8,85 & 147,95 & 7800 \\
2006 & 24,45 & 135,95 & 9,35 & 151,7 & 8650 \\
2007 & 25,15 & 193,95 & 10,4 & 158,45 & 9350 \\
2008 & 20,5 & 178,2 & 7,6 & 167,63 & 6325 \\
2009 & 5,6 & 143,6 & 9,25 & 165,1 & 7087,5 \\
2010 & 3,35 & 67,6 & 8,15 & 133,85 & 6675 \\
2011 & 3,72 & 84,8 & 9,1 & 123,1 & 6350 \\
2012 & 2,62 & 44,1 & 8,4 & 125,45 & 7755 \\
2013 & $-6,73$ & $-16,95$ & 5,5 & 147,6 & 7450 \\
\hline
\end{tabular}

TABEL II

Coefficients

\begin{tabular}{|c|c|c|c|c|c|c|c|c|}
\hline & \multirow{2}{*}{ Model } & \multicolumn{2}{|c|}{$\begin{array}{l}\text { Unstandardized } \\
\text { coefficients }\end{array}$} & \multirow{2}{*}{$\begin{array}{c}\text { Standardize } \\
\text { d } \\
\text { coefficients }\end{array}$} & \multirow{2}{*}{$\mathbf{T}$} & \multirow{2}{*}{ Sig. } & \multicolumn{2}{|c|}{ Collinearity statistics } \\
\hline & & B & $\begin{array}{l}\text { Std. } \\
\text { Error }\end{array}$ & & & & Tolerance & VIF \\
\hline \multirow[t]{5}{*}{1} & (constant) & 3.838 & .734 & & 5.231 & .003 & & \\
\hline & ROE & .149 & .024 & .933 & 6.097 & .002 & .386 & 2.589 \\
\hline & EPS & -385 & 044 & -2.016 & -8.807 & .000 & .173 & 5.786 \\
\hline & ROA & 1.407 & .155 & 1.629 & 9.060 & .000 & .280 & 3.570 \\
\hline & DER & .702 & .139 & .561 & 5.062 & .004 & .737 & 1.357 \\
\hline
\end{tabular}

Sumber : Hasil Penelitian, 2014

Berdasarkan tabel II didapatkan persamaan regeresi berganda :

$$
\mathrm{Y}=3,838+0,149 \mathrm{X} 1-0,385 \mathrm{X} 2+0,702 \mathrm{X} 4
$$

Dengan keterangan : Nilai konstanta pada persamaan regresi diatas sebesar 3,838. Artinya konstanta sebesar 3,838 menunjukkan, jika variabel independen tidak berubah atau tetap (0), maka harga saham akan meningkat sebesar 3,838. Nilai b1 sebesar 0,149. Artinya setiap kenaikan ROE sebesar satu satuan akan mengakibatkan Y meningkat sebesar 0,149. Nilai b2 sebesar -0,385. Artinya setiap kenaikan EPS sebesar satu satuan mengakibatkan Y menurun sebesar 0,385. Nilai b3 sebesar 1,407. Artinya setiap kenaikan ROA sebesar satu satuan akan mengakibatkan Y meningkat sebesar 1,407. Nilai b4 sebesar 0,702. Artinya setiap kenaikan DER sebesar satu satuan akan mengakibatkan Y meningkat sebesar 0,702

Cara mendeteksi ada atau tidaknya masalah multikolinearitas adalah dengan cara melihat VIF hitungnya. Jika VIF hitung lebih kecil dari 10, maka tidak terdapat masalah multikolinearitas pada variabel independennya. 
TABEL III.

Keputusan Multikolinearitas

\begin{tabular}{|c|c|c|c|}
\hline No & Variabel & VIF Hitung & Keterangan \\
\hline 1 & ROE & 2,589 & VIF $<10$, tidak terdapat multikolinearitas \\
2 & EPS & 5,789 & VIF $<10$, tidak terdapat multikolinearitas \\
3 & ROA & 3,570 & VIF $<10$, tidak terdapat multikolinearitas \\
4 & DER & 1,357 & VIF $<10$, tidak terdapat multikolinearitas \\
\hline
\end{tabular}

Sumber : Hasil Penelitian, 2014

Maka, dalam penelitian ini tidak dapat ditemukannya masalah multikolinearitas.

Tabel IV.

Hasil Uji Korelasi Berganda

\begin{tabular}{|c|c|r|r|r|r|}
\hline Model & R & R square & \multicolumn{1}{c|}{ Adjusted R square } & Std. Error of the Estimate & Durbin-watson \\
\hline 1 & .977 & .955 & .919 & .0423272247276 & 3.515 \\
\hline
\end{tabular}

Sumber : Hasil Penelitian,2014

Tabel IV tersebut, menunjukkan bahwa ROE, EPS, ROA, DER, secara bersamaan memiliki hubungan terhadap harga saham sebesar 0,977. Dalam tabel V tersebut, koefisien determinasi atau adjusted $\mathrm{R}$ square sebesar 0,919. Artinya, Y menjelaskan variabel X1,X2,X3, dan X4 sebesar 91,9\% sedangkan 8,1\% (100\%$91,9 \%=81 \%$ ) dipengaruhi faktor lainnya.

Untuk menguji pengaruh variabel independen secara sendiri-sendiri terhadap variabel dependen, jadi akan digunakan uji-t. dalam tabel V sebagai berikut:

\section{Tabel V}

\section{Hasil Thitung dan signifikansi}

\begin{tabular}{|c|c|c|c|c|}
\hline No & Variabel & Thitung & Signifikansi & Keterangan \\
\hline 1 & ROE & 6,097 & 0,002 & Sig $<0,005$, signifikan \\
2 & EPS & $-8,807$ & 0,000 & Sig $<0,005$, signifikan \\
3 & ROA & 9,060 & 0,000 & Sig $<0,005$, signifikan \\
4 & DER & 5,062 & 0,004 & Sig $<0,005$, signifikan \\
\hline
\end{tabular}

Sumber : Hasil Penelitian, 2014

Berdasarkan tabel $\mathrm{V}$ diatas, menunjukkan variabel ROE,EPS,ROA,dan DER mempunyai signifikansi masing-masing 0,002,0,000,0,000,dan 0,004 lebih kecil dari alpha 5\%. Artinya ini H0 diterima, sedangkan variabel ROE,EPS,ROA,dan DER mempengaruhi harga saham secara mandiri. Untuk menguji pengaruh variabel independen secara bersamaan terhadap variabel dependen, maka digunakan uji $\mathrm{f}$. hasil dari hitungan spss,nilai $\mathrm{F}$ hitung adalah sebesar 26,369 dengan signifikansi sebesar 0,001. Maka demikian signifikansi Fhitung sebesar 0,001 lebih kecil dari alpha 0.05 maka H0 diterima. Jadi, variabel independen secara bersamaan mempengaruhi variabel dependen.

Penelitian ini, menunjukkan ROE berpengaruh secara signifikan terhadap harga saham perusahaan telekomunikasi. Ini menggambarkan bahwa kemampuan 
perusahaan mendapatkan hasil laba atas modal yang dimilikinya sehingga pengaruh terhadap harga saham. Sedangkan hasil penelitian dari EPS mempengaruhi signifikan terhadap harga saham. Artinya, investor akan lebih minati saham yang dimiliki EPS tinggi dibandingkan dengan saham yang dimiliki EPS rendah. Karena, semakin banyak investor yang minati saham ini, maka akan membuat harga saham naik, sedangkan EPS yang rendah, cenderung akan menurunkan harga saham. Jikalau hasil penelitian dari ROA, menunjukkan ROA pengaruhi secara signifikan terhadap harga saham. Artinya ini, kemampuan perusahaan memperoleh laba atas aset yang dimilikinya, kemampuan mengendalikan biaya operasional dan non operasional cukup tinggi sehingga menjadi pengaruh terhadap harga saham. Semakin banyak yang minat atas permintaan saham tersebut meningkat, sehingga akan membuat harga saham perusahaan menjadi naik pula. Sedangkan penelitian yang tidak jauh berbeda juga yaitu DER, berpengaruh secara signifikan terhadap harga saham. Bagi bank atau kreditur semakin besar DER akan tidak semakin menguntungkannya karena akan mendapatkan resiko yang besar di tanggung atas kegagalan yang akan terjadi pada perusahaan. Sedangkan bagi perusahaan, semakin besar DER akan semakin menguntungkan karena semakin tinggi tingkat pendanaan yang diberikan pemilik dan semakin besar pula batas pengamanan jika terjadi kerugian ataupun penyusutan nilai aktiva (kasmir 158:2008).

\section{Kesimpulan}

Bahwa, setelah dilakukannya analisis dan pengujian hipotesis pengaruh antara ROE, EPS,ROA,DER terhadap harga saham pada perusahaan telekomunikasi di bursa efek Indonesia pada tahun 2004-2013, dapat diambil kesimpulannya yaitu: konstanta sebesar 3,838 menunjukkan, jika variabel independen tidak berubah atau tetap (0), maka harga saham tersebut akan naik menjadi sebesar 3,838. Koefisien regresi ROE sebesar 0.149 menunjukkan jika ROE naik satu satuan maka akan menyebabkan harga saham naik menjadi 0,149. Koefisien regresi EPS sebesar -0,385 menunjukkan, jika EPS naik satu satuan maka akan menyebabkan harga saham turun menjadi 0,385. Koefisien regresi DER sebesar 0,702 menunjukkan jikalau DER naik, satu satuan maka akan menyebabkan harga saham naik menjadi sebesar 0,702. Dan jika koefisien regresi ROA sebesar 1,407 menunjukkan jika ROA naik satu satuan maka akan menyebabkan harga saham naik menjadi sebesar 1,407. Koefisien determinasi (adjusted $\mathrm{R}$ square) sebesar 0,919 menunjukkan bahwa harga saham menjelaskan variabel $\mathrm{X} 1, \mathrm{X} 2, \mathrm{X} 3, \mathrm{X} 4$ sebesar 91,9\% sedangkan $8,1 \%$ dipengaruhi faktor lainnya. Berdasarkan menurut uji hipotesis (uji-t) bahwa ROE,ROA,DER berpengaruh secara positif dan signifikan. Sedangkan dengan EPS berpengaruh secara negatif dan signifikan. Sedangkan dengan cara uji F, bahwa secara simultan maupun bersama-sama ROE,EPS,ROA,dan DER berpengaruh secara signifikan terhadap harga saham. 


\section{DAFTAR PUSTAKA}

Darmaji, tjiptono, dan Hendy M Fakhruddin.2006.Pasar Modal di Indonesia Pendekatan Tanya Jawab.Jakarta: Salemba Empat.

Fahmi,Irham,2012,Pengantar Pasar Modal,Penerbit Alfabet, Bandung.

Firdaus,Muhammad,2011,Ekonometrika Suatu Pendekatan Aplikatif, Bumi Askara, Jakarta

Joel G.Siegel dan Jae K.Shim,1999,Kamus Istilah Akuntansi,Elek Media Komputindo,Jakarta

Kasmir, 2012,Analisis Laporan Keuangan,Penerbit PT.Raja Grafindo Persada, Jakarta.

Margaretha,Farah,2011,Manajemen Keuangan Untuk Manajer Non Keuangan, Erlangga, Jakarta.

Munir, Fuady,2005,Pengantar Hukum Bisnis: Menata Bisnis Modern di Era Globalisasi,Edisi Revisi,PT. Citra Aditya Bakti,Bandung.

Nachrowi,D Nachrowi, dan Hardius Usman.2006. Pendekatan Populer dan Praktis Ekonometrika Untuk Analisis Ekonomi dan Keuangan. Jakarta: LP FE Universitas Indonesia.

Sartono, Agus,2001,Manajemen Keuangan,Edisi 3, Dosen Fakultas Ekonomi Universitas Gajah Mada,BPFE,Yogyakarta

Sudana, I Made,2011,Manajemen Perusahaan Teori dan Praktik,Erlangga,Jakarta.

Sugiyono, 2007,Metodologi Penelitian Bisnis, Alfabeta,Bandung

Usman, Husaini dan PurnomoSetiadi Akbar,2011, Metodologi Penelitian Sosial, Bumi Askara, Jakarta.

Yuwono,Prapto,2005,Pengantar Ekonometri,Penerbit Andi, Yogyakarta

www.telkom.co.id

www.idx.co.id 